\title{
SENSITIVITY ANALYSIS OF BIOME-BGC MODEL FOR DRY TROPICAL FORESTS OF VINDHYAN HIGHLANDS, INDIA
}

\author{
Manoj Kumar* and A. S. Raghubanshi ${ }^{\mathrm{b}}$ \\ ${ }^{a}$ Ecosystem Analysis Laboratory, Department of Botany, Banaras Hindu University, Varanasi- 221005, India. \\ ${ }^{\mathrm{b}}$ Institute of Environment \& Sustainable Development, Banaras Hindu University, Varanasi- 221005, India. \\ *E-mail: bhu.manoj@gmail.com
}

KEYWORDS: Biome-BGC model, Dry deciduous forest, Net primary productivity, Sensitivity index, Vindhyan highlands.

\begin{abstract}
ABSRACT:
A process-based model BIOME-BGC was run for sensitivity analysis to see the effect of ecophysiological parameters on net primary production (NPP) of dry tropical forest of India. The sensitivity test reveals that the forest NPP was highly sensitive to the following ecophysiological parameters: Canopy light extinction coefficient $(k)$, Canopy average specific leaf area (SLA), New stem C : New leaf C (SC:LC), Maximum stomatal conductance $\left(\mathrm{g}_{\mathrm{s}, \max }\right), \mathrm{C}: \mathrm{N}$ of fine roots $\left(\mathrm{C}: \mathrm{N}_{\mathrm{fr}}\right)$, All-sided to projected leaf area ratio and Canopy water interception coefficient $\left(\mathrm{W}_{\mathrm{int}}\right)$. Therefore, these parameters need more precision and attention during estimation and observation in the field studies.
\end{abstract}

\section{INTRODUCTION}

There are various types of models that may be used in ecosystem analysis. Ruimy et al. (1994), categorized the NPP model into three groups: (1) statistical models (Lieth, 1975), (2) parametric models (Potter et al., 1993) and (3) process models (Foley, 1994). Traditional types of models are regression models, which are based on empirically derived statistical relationships. Such models may be used for predicting stand development under stable conditions and in regions where the built-in relationships were derived. Naturally, such models are not so useful for incorporating changing growth conditions and for spatial extrapolation. Moreover, such models remain descriptive and do not offer much explanatory power for ecosystem analysis. For this, so-called process-based models must be deployed. These models simulate ecosystem development as a result of ecophysiological processes described mechanistically and usually incorporate the effect of environmental change on ecosystem functioning and are able to quantify effects of, e.g., change in climate, elevated $\mathrm{CO}_{2}$, nitrogen deposition and land use scenarios (Cienciala and Tatarinov, 2006).

Sensitivity analysis is the study of how the variation (uncertainty) in the output of a model can be apportioned, qualitatively or quantitatively, to different sources of variation in the input of the model (Xu et al., 2004). It can be used to examine which variables/parameters have the largest effect on the model output. Sensitivity analysis determines what level of accuracy is necessary for a parameter to make the model sufficiently useful and valid. If the sensitivity tests reveal that the model is insensitive to a particular factor, then it may be possible to use an estimate rather than a value with greater.

For ecological analysis Biogeochemical (BGC) model is most preferred. BIOME-BGC (Running and Coughlan, 1988; Thornton, 1998) is such model which employs a simplified biochemical model of photosynthesis, environmentally regulated stomatal conductance, and explicit calculations of respiration for various plant pools to calculate NPP. It is a process-based model requiring a considerable number of ecophysiological and site parameters. Therefore, application of this model requires parameterization, including sensitivity analysis of model output to the input data.

\begin{tabular}{|c|c|}
\hline Parameters & Symbol \\
\hline Allocation current growth proportion & $\mathrm{cg}$ \\
\hline Allocation new coarse root $C$ : new stem $C$ & CRC:SC \\
\hline Allocation New fine root $C$ : New leaf $C$ & FRC:LC \\
\hline All-sided to projected leaf area ratio & $\mathrm{LAI}_{\text {all:pro }}$ \\
\hline Annual fire mortality fraction & $m_{f}$ \\
\hline Annual leaf and fine root turnover fraction & $m_{l} m_{f r}$ \\
\hline Annual live wood turnover fraction & $\mathrm{m}_{\mathrm{w}}$ \\
\hline Annual whole-plant mortality fraction & $m_{t}$ \\
\hline autotrophic respiration & $\mathrm{Ra}$ \\
\hline Boundary layer conductance (projected area basis) & $\mathrm{g}_{\mathrm{bl}}$ \\
\hline $\mathrm{C}: \mathrm{N}$ of dead wood & $C: N_{d w}$ \\
\hline $\mathrm{C}: \mathrm{N}$ of fine roots & $C: \mathrm{N}_{\mathrm{fr}}$ \\
\hline $\mathrm{C}: \mathrm{N}$ of leaf litter, after retranslocation & $\mathrm{C}: \mathrm{N}_{\text {lit }}$ \\
\hline $\begin{array}{l}\mathrm{C}: \mathrm{N} \text { of leaves } \\
\mathrm{C}: \mathrm{N} \text { of live wood }\end{array}$ & $\begin{array}{l}C: \mathrm{N}_{\text {leaf }} \\
C: \mathrm{N}_{\text {lw }}\end{array}$ \\
\hline Canopy average specific leaf area (projected area basis) & SLA \\
\hline Canopy light extinction coefficient & $k$ \\
\hline Canopy water interception coefficient & $\mathrm{W}_{\text {int }}$ \\
\hline Carbon & $\mathrm{C}$ \\
\hline Cuticular conductance (projected area basis) & $\mathrm{g}_{\text {cut }}$ \\
\hline Vapor pressure deficit & VPD \\
\hline Fraction of leaf $\mathrm{N}$ in Rubisco & $\mathrm{N}_{\mathrm{R}}$ \\
\hline Gross primary productivity & GPP \\
\hline Leaf Area Index & LAI \\
\hline Leaf water potential: complete conductance reduction & $\mathrm{LWP}_{\mathrm{f}}$ \\
\hline Leaf water potential: start of conductance reduction & $\mathrm{LWP}_{\mathrm{i}}$ \\
\hline Litter fall as fraction of growing season & $T_{l f}$ \\
\hline Maximum stomatal conductance (projected area basis) & $\mathrm{g}_{\mathrm{s}, \max }$ \\
\hline New live wood $\mathrm{C}:$ new total wood $\mathrm{C}$ & $\begin{array}{l}\text { LWC:T } \\
\text { WC }\end{array}$ \\
\hline New stem $C$ : New leaf $C$ & SC:LC \\
\hline Nitrogen & $\mathrm{N}$ \\
\hline Ratio of shaded SLA:sunlit SLA & SLA $_{\text {shd:su }}$ \\
\hline Transfer growth period & \\
\hline Vapor pressure deficit: Complete conductance reduction & $\mathrm{VPD}_{\mathrm{f}}$ \\
\hline Vapor pressure deficit: Start of conductance reduction & $\mathrm{VPD}_{\mathrm{i}}$ \\
\hline
\end{tabular}

Table 1: List of abbreviations 
Previously, sensitivity analysis for BIOME-BGC (BioGeochemical Cycles) model has been conducted by White et al. (2000) and Tatarinov and Cienciala (2006) for temperate biomes. Reassessment of model sensitivity for dry tropical forest of India is needed because effect of parameters for different combinations of site and eco-physiological parameters may differ. Therefore, the aim of the present study is (i) to collect ecophysiological and site parameters for dry tropical forest of India from available literature and observations and (ii) to reveal the effect of ecophysiological parameters on NPP and also identify critically sensitive input parameters.

\section{MATERIAL AND METHODS}

\subsection{BIOME-BGC model description}

The BIOME-BGC version 4.1.2 was provided by Peter Thornton at the National Center for Atmospheric Research (NCAR), and the Numerical Terradynamic Simulation Group (NTSG) at the University of Montana (available online at http://www.ntsg.umt.edu.). The model is used for this study along with MT-CLIM (Mountain Microclimate Simulator). BIOMEBGC (Thornton 1998, 2000) is a biogeochemical model that simulates the storage and fluxes of water, $\mathrm{C}$ and $\mathrm{N}$ in terrestrial ecosystems using a daily time step and at different ecological scales (Churkina et al., 2003). The model requires daily weather data including radiation, maximum and minimum temperatures, precipitation and daytime VPD. It also requires information describing the soil properties (Table 2) and eco-physiological traits of vegetation (Table 3). Allometric relationships are used to initialize plant and soil $\mathrm{C}$ and $\mathrm{N}$ pools based on the leaf pools of these elements. BIOME-BGC estimates NPP on the basis of GPP and Ra (i.e. NPP).

\begin{tabular}{lll}
\hline Parameters & Value & Sources \\
\hline Number of meteorological year & 25 & This study \\
Number of simulation years & 25 & This study \\
First year for simulation & 1986 & This study \\
Constant atmospheric $\mathrm{CO}_{2}(\mathrm{ppm})$ & 390 & This study (LiCor -6400$)$ \\
Effective soil depth $(\mathrm{m})$ & 0.15 & Singh and Singh 1991 \\
Sand percentage by volume in rock-free soil (\%) & 69.0 & Singh and Singh 1991 \\
Silt percentage by volume in rock-free soil $(\%)$ & 27.0 & Singh and Singh 1991 \\
Clay percentage by volume in rock-free soil $(\%)$ & 04.0 & Singh and Singh 1991 \\
Site elevation $(\mathrm{m})$ & 172 & This study \\
Site latitude $\left({ }^{\circ} \mathrm{N}\right)$ & 25 & This study \\
Wet + dry atmospheric deposition of $\mathrm{N}\left(\mathrm{KgN} / \mathrm{m}^{2} / \mathrm{yr}\right)$ & 0.0001 & Pathak et al. 2009 \\
Symbiotic + asymbiotic fixation of $\left(\mathrm{KgN} / \mathrm{m}^{2} / \mathrm{yr}\right)$ & 0.0004 & Pathak et al. 2009 \\
\hline
\end{tabular}

Table 2: Model input parameters for site characteristics

\subsection{Sensitivity analysis}

Sensitivity analysis was performed as documented in Cienciala and Tatarinov (2006), "output variables (y) to input parameters (x) (or the effect of parameter $\mathrm{x}$ on the variable $\mathrm{y}$ ), $\Delta \mathrm{y} / \Delta \mathrm{x}$ was calculated as a ratio of output variable change to parameter change (both in \%)". A negative ratio would mean a decrease in variable with an increased parameter value and vice versa (Cienciala and Tatarinov 2006). As for the absolute quantity $(|\Delta y / \Delta x|)$, the parameters were ranked in terms of their effect on the modeled variable as (i) parameters with a strong effect $(|\Delta \mathrm{y} / \Delta \mathrm{x}|$ larger than 0.2), (ii) parameters with a medium effect $(|\Delta y / \Delta x|$ between 0.1 and 0.2$)$ and (iii) parameters with low effect $(|\Delta \mathrm{y} / \Delta \mathrm{x}|$ less than 0.1$)$.

\subsection{Study area}

The study area is located on the Vindhyan Plateau in the Marihan range of East Mirzapur Forest Division of Uttar Pradesh, India, at

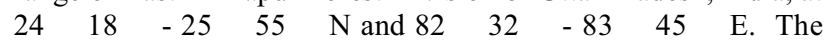
total forest area in this block is 10360 ha. The climate is tropical and characterized by monsoon conditions. There are three seasons: rainy (mid June - Sept.), winter (November - February) and summer (March - mid June). The mean monthly temperatue varies from $17.5 \mathrm{C}$ (January) to $37.5 \mathrm{C}$ (May) and total annual rainfall averages $821 \mathrm{~mm}$, of which $86 \%$ occurs in the rainy season. The potential natural vegetation is northern tropical dry deciduous forest (Champion and Seth, 1968). The details about dominated species of study area were described by Singh and Singh (1991).

\section{RESULT}

Sensitivity analysis for eco-physiological parameters revealed that SLA, $\mathrm{g}_{\mathrm{s}, \max }, \mathrm{W}_{\text {int }}$ and $\mathrm{LAI}_{\text {all:pro }}$ exert a strong negative effect on NPP, while $k$, SC:LC and C: $\mathrm{N}_{\text {fr }}$ showed positive effect (Table 3). $C: \mathrm{N}_{\text {lit }}, \mathrm{N}_{\mathrm{R}}, \mathrm{CRC}: \mathrm{SC}$ and $\mathrm{C}: \mathrm{N}_{\text {leaf }}$ showed positive medium effect on NPP (Table 3). Input parameters like SLA shd:su, $T_{t}, \mathrm{VPD}_{\mathrm{i}}, m_{t}$, $\mathrm{LWP}_{\mathrm{f}}, \mathrm{FRC}: \mathrm{LC}, T_{l f}, \mathrm{VPD}_{\mathrm{f}}$ etc. had low sensitivity to model output value of NPP (Table 4). $m_{l} m_{f r}$, LWC:TWC, $\mathrm{g}_{\text {cut }}$ has produced almost negligible effect on the sensitivity of the model.

\section{DISCUSSION}

For dry tropical forest observed $k$ had a high positive impact on NPP. The value of $k$ depends upon intercepted photosynthetically active radiation (PAR) and LAI (Lagergren et al. 2005). LAI has major influence on BIOME-BGC since it controls canopy radiation absorption, water interception, photosynthesis, and litter inputs to detrital pools (White et al. 2000). Increased specific leaf area $(\mathrm{SLA})$ resulted in higher LAI $(\mathrm{LAI}=\mathrm{SLA} \times$ leaf carbon) without altering photosynthetic capacity, increasing water stress and thereby reducing NPP (White et al. 2000). SC:LC allocation ratio has a high positive effect on NPP of dry tropical forest. This 
is due to the redistribution of biomass into the woody compartment with a low turnover rate (Tatarinov and Cienciala 2006). Maximum stomatal conductance $\left(\mathrm{g}_{\mathrm{s}, \max }\right)$ showed a negatively high sensitivity to NPP; this was in contrast to the report of European temperate managed forestry (Tatarinov and Cienciala 2006). Increases in $\mathrm{g}_{\mathrm{s}, \max }$ reduced NPP by increasing water stress. Increased $\mathrm{C}: \mathrm{N}_{\mathrm{fr}}$, reduces root nitrogen requirements and diverts nitrogen to increased photosynthetic capacity which promotes higher NPP for most biomes (White et al. 2000).

Fraction of leaf $\mathrm{N}$ in Rubisco of dry tropical forest showed positive sensitivity to NPP similar to major natural temperate biomes (White et al. 2000) and for beech and small or medium spruce species (Tatarinov and Cienciala 2006). This effect follows from the fact that maximum rate of carboxylation in the model is proportional to $\mathrm{N}_{\mathrm{R}}$ (Tatarinov and Cienciala 2006). The effect of the $\mathrm{C}: \mathrm{Nl}_{\text {leaf }}$ was similar to the report of Tatarinov and Cienciala (2006) for beach species which was in contrast to White et al. (2000), who found, that the increase of C: $\mathrm{N}_{\text {leaf }}$ decreased NPP in all woody biomes. Such an ambiguous effect of $\mathrm{C}: \mathrm{N}_{\text {leaf }}$ might be due to the trade-off between the increase of photosynthesis and foliage respiration with an increasing foliage nitrogen content (Tatarinov and Cienciala 2006). VPD $\mathrm{V}_{\mathrm{i}}$ and $\mathrm{VPD}_{\mathrm{f}}$ showed low negative effect on NPP. This negative relation with NPP was due to increased VPD which causes closure of stomata resulting in inhibition of photosynthesis (Jarvis 1976; Stewart 1988). Fire mortality also had a low negative effect on NPP, which primarily occurs in summer season in dry deciduous forest, i.e., it is affected by fire mortality for a shorter time (Tatarinov and Cienciala 2006).

\begin{tabular}{|c|c|c|c|}
\hline Parameters & Type & Value & Sources \\
\hline Year day to start new growth & Day of year & 105 & Singh and Kushwaha, 2005 \\
\hline Year day to end litterfall & Day of year & 364 & Singh et al., 1992 \\
\hline$T_{l f}$ & Prop. & 0.45 & Singh and Kushwaha, 2005 \\
\hline $\mathrm{m}_{\mathrm{w}}$ & Year $^{-1}$ & 0.70 & White et al., 2000 \\
\hline$m_{t}$ & Year $^{-1}$ & 0.048 & Singh and Singh, 1993 \\
\hline$m_{f}$ & Year $^{-1}$ & 0.005 & Stipulated \\
\hline FRC:LC & Ratio & 1.0 & Singh and Singh, 1991; Chaturvedi and Raghubanshi, 2011 \\
\hline Allocation of SC:LC & Ratio & 2.2 & Singh and Singh, 1991; Chaturvedi and Raghubanshi, 2011 \\
\hline Allocation of LWC:TWC & Ratio & 0.1 & DVM \\
\hline $\mathrm{CRC}: \mathrm{SC}$ & Ratio & 0.4 & Singh, 1990 \\
\hline Allocation current growth proportion & Prop. & 0.5 & Chaturvedi and Raghubanshi, 2011 \\
\hline$C: \mathrm{N}_{\text {leaf }}$ & $\mathrm{KgC} / \mathrm{KgN}$ & 20.3 & Tripathi and Singh, 1992; Raghubanshi, 2008 \\
\hline $\mathrm{C}: \mathrm{N}_{\text {lit }}$ & $\mathrm{KgC} / \mathrm{KgN}$ & 74.6 & Singh, 1990; Singh et al., 1991 \\
\hline $\mathrm{C}: \mathrm{N}_{\mathrm{fr}}$ & $\mathrm{KgC} / \mathrm{KgN}$ & 48.2 & Tripathi and Singh, 1992; Raghubanshi, 2008 \\
\hline $\mathrm{C}: \mathrm{N}_{\mathrm{lw}}$ & $\mathrm{KgC} / \mathrm{KgN}$ & 78.3 & Tripathi and Singh, 1992; Raghubanshi 2008 \\
\hline $\mathrm{C}: \mathrm{N}_{\mathrm{dw}}$ & $\mathrm{KgC} / \mathrm{KgN}$ & 442.0 & DVM \\
\hline Leaf litter labile proportion & DIM & 0.28 & Singh et al, 1999 \\
\hline Leaf litter cellulose proportion & DIM & 0.47 & Singh et al, 1999 \\
\hline Leaf litter lignin proportion & DIM & 0.25 & Singh et al, 1999 \\
\hline Fine root labile proportion & DIM & 0.30 & DVM \\
\hline Fine root cellulose proportion & DIM & 0.45 & DVM \\
\hline Fine root lignin proportion & DIM & 0.25 & DVM \\
\hline Dead wood cellulose proportion & DIM & 0.76 & DVM \\
\hline Dead wood lignin proportion & DIM & 0.24 & DVM \\
\hline Canopy water interception coefficient & $\mathrm{LAI}^{-1} \mathrm{~d}^{-1}$ & 0.041 & DVM \\
\hline$k$ & DIM & 0.5 & Maass et al., 1994 \\
\hline $\mathrm{LAI}_{\text {all:pro }}$ & DIM & 2.0 & White et al., 2000 \\
\hline SLA & $\mathrm{m} 2 / \mathrm{kgC}$ & 30.0 & Chaturvedi and Raghubanshi, 2011 \\
\hline SLA $_{\text {shd:su }}$ & DIM & 2.0 & White et al. 2000 \\
\hline $\mathrm{N}_{\mathrm{R}}$ & DIM & 0.08 & Default value of DBF biome \\
\hline $\mathrm{g}_{\mathrm{s}, \max }$ & $\mathrm{m} \mathrm{s}^{-1}$ & 0.006 & This study \\
\hline $\mathrm{g}_{\text {cut }}$ & $\mathrm{m} \mathrm{s}^{-1}$ & 0.00001 & This Study \\
\hline $\mathrm{g}_{\mathrm{bl}}$ & $\mathrm{m} \mathrm{s}^{-1}$ & 0.08 & This study \\
\hline $\mathrm{LWP}_{\mathrm{f}}$ & $\mathrm{MPa}$ & -1.8 & Chaturvedi and Raghubanshi, 2011 \\
\hline $\mathrm{VPD}_{\mathrm{i}}$ & $\mathrm{Pa}$ & 930.0 & This study \\
\hline $\mathrm{VPD}_{\mathrm{f}}$ & $\mathrm{Pa}$ & 4100.0 & This study \\
\hline
\end{tabular}

Table 3: Ecophysiological input parameters for model (*DVM = Default value of model for deciduous broadleaf forest (DBF) biome as White et al. (2000)) 


\begin{tabular}{|c|c|c|}
\hline Parameters & Units & SI \\
\hline$k$ & (DIM) & 0.40 \\
\hline SLA & $(\mathrm{m} 2 / \mathrm{kgC})$ & -0.36 \\
\hline SC:LC & (ratio) & 0.34 \\
\hline $\mathrm{g}_{\mathrm{s}, \max }$ & $(\mathrm{m} / \mathrm{s})$ & -0.31 \\
\hline$C: N_{\text {fr }}$ & $(\mathrm{kgC} / \mathrm{kgN})$ & 0.29 \\
\hline $\mathrm{W}_{\mathrm{int}}$ & $(1 / \mathrm{LAI} / \mathrm{d})$ & -0.21 \\
\hline $\mathrm{LAI}_{\text {all:pro }}$ & (DIM) & -0.21 \\
\hline $\mathrm{C}: \mathrm{N}_{\text {lit }}$ & $(\mathrm{kgC} / \mathrm{kgN})$ & 0.18 \\
\hline $\mathrm{N}_{\mathrm{R}}$ & (DIM) & 0.15 \\
\hline $\mathrm{CRC}: \mathrm{SC}$ & (ratio) & 0.10 \\
\hline$C: \mathrm{N}_{\text {leaf }}$ & $(\mathrm{kgC} / \mathrm{kgN})$ & 0.10 \\
\hline SLA $_{\text {shd:su }}$ & (DIM) & 0.09 \\
\hline$T_{t}$ & (prop.) & 0.08 \\
\hline $\mathrm{VPD}_{\mathrm{i}}$ & $(\mathrm{Pa})$ & -0.08 \\
\hline$m_{t}$ & $(1 / y r)$ & -0.07 \\
\hline $\mathrm{LWP}_{\mathrm{f}}$ & $(\mathrm{MPa})$ & 0.06 \\
\hline FRC:LC & (ratio) & -0.06 \\
\hline$T_{l f}$ & (prop.) & 0.04 \\
\hline $\mathrm{VPD}_{\mathrm{f}}$ & $(\mathrm{Pa})$ & -0.04 \\
\hline $\mathrm{C}: \mathrm{N}_{\mathrm{dw}}$ & $(\mathrm{kgC} / \mathrm{kgN})$ & 0.03 \\
\hline $\mathrm{g}_{\mathrm{bl}}$ & $(\mathrm{m} / \mathrm{s})$ & 0.03 \\
\hline $\mathrm{m}_{\mathrm{w}}$ & $(1 / \mathrm{yr})$ & 0.03 \\
\hline $\mathrm{LWP}_{\mathrm{i}}$ & $(\mathrm{MPa})$ & -0.03 \\
\hline$C: \mathrm{N}_{\mathrm{lw}}$ & $(\mathrm{kgC} / \mathrm{kgN})$ & 0.02 \\
\hline LWC:TWC & (ratio) & -0.02 \\
\hline$m_{f}$ & $(1 / y r)$ & -0.01 \\
\hline $\mathrm{cg}$ & (prop.) & 0.00 \\
\hline $\mathrm{g}_{\text {cut }}$ & $(\mathrm{m} / \mathrm{s})$ & 0.00 \\
\hline$m_{l} m_{f r}$ & $(1 / y r)$ & 0.00 \\
\hline
\end{tabular}

Table 4: Sensitivity Index (SI) for Ecophysiological parameters

\section{CONCLUSION}

The study identified key eco-physiological parameters of a process model BIOME-BGC based on a detailed sensitivity analysis. Among the eco-physiological parameters $k$, SLA, $\mathrm{SC}: \mathrm{LC}, \mathrm{g}_{\mathrm{s}, \max }, \mathrm{C}: \mathrm{N}_{\text {fr }}, \mathrm{LAI}_{\text {all:pro }}$ and $\mathrm{W}_{\text {int }}$ showed the strongest effect on simulated NPP. Four ecophysiological parameter viz., C: $\mathrm{N}_{\text {lit, }}$, $\mathrm{N}_{R}, C: \mathrm{N}_{\text {leaf }}$ and CRC:SC had medium influence on simulated NPP value. Therefore these parameters need more precision and attention during estimation and observation in the field study.

\section{REFERENCES}

Champion, H.G. and Seth, S.K., 1968. A revised survey of the forest types of India. Government of India Publications, New Delhi.

Chaturvedi, R.K., Raghubanshi, A.S. 2011. Plant Functional Traits in a Tropical Deciduous Forest; An Analysis. Lambert Academic Publishing Gmbh \& Co. KG, Germany.

Churkina G, Tenhunen J., Thornton, P, Falge, E.M., Elbers J.A., Erhard M., Grünwald, T., Kowalski, A.S., Rannik, Ü., Sprinz, D.,
2003. Analyzing the ecosystem carbon dynamics of four European coniferous forests using a biogeochemistry model. Ecosystems, 6, pp.168-84.

Cienciala E. and Tatarinov F.A., 2006. Application of BIOMEBGC model to managed forests 2. Comparison with long-term observations of stand production for major tree species. Forest Ecol Manag, 237, pp. 252-266.

Foley, J.A., 1994. Net primary productivity in the terrestrial biosphere: the application of a global model. J. Geophys. Res. 99, 20773-20783.

Lagergren, F., Eklundh, L., Grelle A., Lundblad, M., Mölder, M., Lankreijer, H. and Lindroth A., 2005. Net primary production and light use efficiency in a mixed coniferous forest in Sweden. Plant Cell Environ, 28, pp. 412-423.

Lieth, H., 1975. Modeling the primary productivity of the world. In: Lieth, H., Whittaker, R.H. (Eds.), Primary Productivity of the Biosphere. Springer-Verlag, New York, pp. 237-263.

Luo, Z., Sun, O.J, Wang, E., Ren, H. and Xu H., 2010. Modeling Productivity in Mangrove Forests as Impacted by Effective Soil Water Availability and Its Sensitivityto Climate Change Using Biome-BGC. Ecosystems, 13, pp. 949-965.

Maass, J.M., Vose, J.M., Swank, W.T., Martinez-Yrizar A., 1995. Seasonal changes of leaf area index (LAI) in a tropical deciduous forest in west Mexico. Forest Ecol Manag, 74, pp.171-180.

Pathak, H., mohanty, S., Prasad, R., 2009. Fate of nitrogen in Indian agriculture: environmental impacts, quantification and uncertainties - A review. Proc. Nat. Acad. Sci. India, 79, 331 345 .

Potter, C.S., Randerson, J.T., Field, C.B., Matson P.A., Vitousek, P.M., Mooney, H.A. et al. 1993. Terrestrial ecosystem production - a process model-based on global satellite and surface data. Global Biogeochem Cy, 7, PP. $811-841$.

Raghubanshi, A.S., 2008. Nitrogen cycling in Indian terrestrial natural ecosystems. Current Sci, 94,11, pp. 1404-1412.

Ruimy, A., Saugier, B., Dedieu, G., 1994. Methodology for the estimation of terrestrial net primary production from remotely sensed data. J Geophys Res, 99, 5263-5383.

Running, S.W. and Coughlan J.C., 1988. A general model of forest ecosystem processes for regional applications. I. Hydrological balance, canopy gas exchange and primary production processes. Ecol Model, 42, pp. 125-154.

Singh, J.S., and Singh, V.K., 1992. Phenology of seasonally dry tropical forest. Curr Sci, 63(11), pp. 684-689.

Singh, K.P. and Kushwaha C.P., 2005. Paradox of leaf phenology: Shorea robusta is a semi-evergreen species in tropical dry deciduous forests in India. Curr Sci, 88, 1820 - 1824.

Singh, L. and Singh, J. S., 1991. Storage and flux of nutrient in a dry tropical forest in India. Ann. Bot. 68: pp 275-284.

Singh, L. Singh, J. S., 1993. Importance of short-lived components of a dry tropical forest for biomass production and nutrient cycling. J Veg Sci 4, pp. 681-686. 
International Archives of the Photogrammetry, Remote Sensing and Spatial Information Sciences, Volume XXXVIII-8/W20, 2011 ISPRS Bhopal 2011 Workshop, 8 November 2011, Bhopal, India

ISPRS Archives XXXVIII- 8/W20; Workshop Proceedings: Earth Observation for Terrestrial Ecosystems

Singh, L., 1990. Biomass Production and Nutrient Dyanamics in a Dry Tropical Forest. Ph.D. thesis, Banaras Hindu University, pp80-120.

Tatarinov F. A. and Cienciala E. 2006. Application of BIOMEBGC model to managed forests 1 . Sensitivity analysis. Forest Ecol Manag, 237, pp. 267-279.

Thornton, P.E., 1998. Description of a Numerical Simulation Model for Predicting the Dynamics of Energy, Water, Carbon, and Nitrogen in a Terrestrial Ecosystem, Ph.D. Thesis, Univ. Montana, Missoula, MT, pp 280.

Tripathi, S.K., and Singh, K.P., 1992; Nutrient immobilization and release patterns during plant decomposition in a dry tropical bamboo savanna, India. Biol Fertil Soils, 14, pp. 191199.

White, M.A., Thornton, P.E., Running, S.W., and Nemani, R., 2000. Parameterization and Sensitivity Analysis of the BIOME-
BGC Terrestrial Ecosystem Model: Net Primary Production Controls. Earth Interact, 4:003, pp.1-85.

Xu, C., Hu, Y., Chang, Y., Jiang, Y., Li, X., Bu, R., He., H., 2004. Sensitivity analysis in ecological modelling. J App Ecol 15:105662 .

\section{ACKNOWLEDGEMENTS}

Biome-BGC version 4.1.1 was provided by the Numerical Terradynamic Simulation Group (NTSG) at the University of Montana. NTSG assumes no responsibility for the proper use of Biome-BGC by others. The authors are thankful to the ISROSAC (Space Application Centre) for funding support through "Energy Mass Exchange in Vegetation System" project. MK thankfully acknowledges Council of Scientific and Industrial Research, India for funding support. 